\title{
ХАРАКТЕР МІНЛИВОСТІ ІНБРЕДНИХ ЛІНІЙ КУКУРУДЗИ В УМОВАХ ПРАВОБЕРЕЖНОГО ЛІСОСТЕПУ УКРАЇНИ
}

\section{С. П. КОЦЮБА, кандидат сільськогосподарських наук Уманський національний університет садівництва}

Викладено результати аналізу мінливості інбредних ліній кукурудзи в умовах Правобережного Лісостепу Украӥни. Ступінь мінливості конкретної ознаки має важливе значення для оиінки колекиї інбредних ліній, щэо аналізувалися. Статистичні характеристики щодо врожайності, вказують на те, що дисперсія $\left(S^{2}=0,68\right)$ низька, а отже інбредні лінії, що входять до колекиї мало реагують на коливання умов вирощування зміною врожайності. $B$ той же час, коефіиієєт варіації, щцо складає 22,28 \% вказує, щุо між окремими інбредними лініями є різниия і ї̈ варто оиінити детальніме.

Ключові слова: кукурудза, інбредна лінія, мінливість, варіабельність, дисперсія, коефіuієнт варіаціï.

Аналіз останніх досліджень і публікацій. На сучасному етапі розвитку селекційної науки інбредні лінії є основним джерелом для створення нових генотипових комбінацій для різних селекційних програм $[1,2,3]$.

Дисперсія та коефіцієнт варіації за врожайністю інбредних ліній у першу чергу вказують на контрастність і різну потенційну можливість вивченого матеріалу, що дає підстави аналізувати їх комбінаційну здатність у діалельних схрещуваннях та інших схемах без застережень для наступного добору за комбінаційною здатністю $[4,5,6]$. 
Після встановлення середньої величини виникає питання, в якій мірі індивідуальні значення ознаки відрізняються між собою та від середньої. Для цього розраховують показники варіації.

Чим більший коефіцієнт варіації, тим менш однорідна сукупність і тим менш типова середня для даної сукупності. Встановлено, що сукупність кількісно однорідна, якщо коефіцієнт варіації не перевищує 33 \%. До основних абсолютних і відносних показників, що характеризують варіацію, $є$ такі: розмах варіації; середнє лінійне відхилення, дисперсія, середнє квадратичне відхилення, коефіцієнт варіації тощо

В одних сукупностях індивідуальні значення ознаки щільно групуються навколо центру розподілу, в інших - значно відхиляються. Чим менше відхилення, тим однорідніша сукупність [8, 9].

Методика досліджень. Досліди було проведено за методиками, що використовуються у селекції кукурудзи в більшості селекційних установ України $[10,11,12]$.

Для обрахунку експериментальних даних використовували методи дисперсійного і кореляційного аналізів [12] за використання комп'ютерних програм.

Результати досліджень. У наших дослідженнях рішення щодо включення вихідного матеріалу в програми створення гібридів приймали з урахуванням варіабельності інбредних ліній за окремими ознаками та прояву їхнього продуктивного потенціалу.

Ступінь мінливості конкретної ознаки має важливе значення для оцінки колекції проаналізованих інбредних ліній. Серед багатьох показників, за якими оцінюють фенотипну варіабельність як популяції, що являє собою колекція, їі окремих компонентів, що у нашому випадку $є$ інбредні лінії цієї колекції, найважливішими вважаються середнє квадратичне відхилення (S), за яким розраховують дисперсію $\left(\mathrm{S}^{2}\right)$. Саме середнє квадратичне відхилення дає змогу встановити різні показники мінливості як вище згадана дисперсія, так i коефіцієнт варіації (V). Проте коефіцієнт варіації дає універсальнішу 
інформацію щодо мінливості за іï відносними величинами, тобто порівняти варіабельність ознак, що не можна порівняти за показниками середніх арифметичних.

Дисперсія та коефіцієнт варіації за врожайністю інбредних ліній у першу чергу вказують на контрастність i різну потенційну можливість проаналізованого матеріалу, що дає підстави аналізувати їх комбінаційну здатність у діалельних схрещуваннях та інших схемах без застережень для наступного добору за комбінаційною здатністю [4-6].

Дані наведені в таблиці 1 вказують на мінливість середніх арифметичних показників колекції. Статистичні характеристики щодо урожайності вказують на те, що дисперсія $\left(\mathrm{S}^{2}=0,68\right)$ низька, а отже інбредні лінії, що входять до колекції мало реагують на умови вирощування зміною врожайності. В той же час коефіцієнт варіації, що складає 22,28 \% вказує, що між окремими інбредними лініями є різниця і їі варто оцінити детальнтше.

В той же час незначне ( $\mathrm{V}=4,96 \%$ ) варіювання тривалості періоду від сходів до повної стиглості та кількості листків на основному стеблі ( $\mathrm{V}=7,73$ \%), що вказує на вирівняність колекції за цими показниками.

Стосовно дисперсії, то у першому випадку за тривалістю вегетації мінливість була вищою $\left(S^{2}=32,79\right)$, ніж у другому $\left(S^{2}=1,27\right)$. Низька мінливість кількості листків на основному стеблі є підставою для використання саме цого показника за оцінки скоростиглості кукурудзи. Цей критерій можна вважати найнадійнішим у випадках генетичного поліморфізму вихідного матеріалу, за походженням. Щодо споріднених ліній цілком можна керуватися $\mathrm{i}$ критеріями ФАО [13].

Невелика варіабельність показників вологості зерна при збиранні $\left(\mathrm{S}^{2}=\right.$ 8,$76 ; \mathrm{V}=12,6$ \%) свідчить про перспективи даного критерію, як додаткового, в оцінці рівня скоростиглості досліджуваного селекційного матеріалу. Високі значення коефіцієнтів варіації та висока експресивність варіанс ознак „висота прикріплення качана” і „висота рослини” засвідчує істотну фенотипову та генотипову різноманітність матеріалу за цими ознаками. 
Табл. 1. Варіабельність господарсько-цінних ознак у інбредних ліній кукурудзи за 2016-2019 роки

\begin{tabular}{|l|c|c|c|c|c|}
\hline \multirow{2}{*}{\multicolumn{1}{|c|}{ Показник }} & \multicolumn{5}{|c|}{ Статистична характеристика } \\
\cline { 2 - 6 } & $\begin{array}{c}\text { середнє } \\
\text { арифме } \\
\text { тичне }\end{array}$ & дисперсія & $\begin{array}{c}\text { коріюеніцієнт } \\
\%\end{array}$ & $\begin{array}{c}\text { похибка } \\
\text { середнього } \\
\text { арифметич } \\
\text { ного }\end{array}$ & $\begin{array}{c}\text { відносна } \\
\text { похибка } \\
\text { середнього } \\
\text { арифметич } \\
\text { ного }\end{array}$ \\
\hline Урожайність, т/га & 3,58 & 0,68 & 22,28 & 0,09 & 2,51 \\
\hline $\begin{array}{l}\text { Тривалість вегетації, } \\
\text { днів }\end{array}$ & 115,43 & 32,79 & 4,96 & 0,72 & 0,62 \\
\hline Висота рослини, см & 146,77 & 323,87 & 12,26 & 1,18 & 2,20 \\
\hline $\begin{array}{l}\text { Висота } \\
\text { прикріплення } \\
\text { качана, см }\end{array}$ & 53,53 & 90,41 & 17,76 & 5,43 & 3,69 \\
\hline $\begin{array}{l}\text { Кількість листків на } \\
\text { основному стеблі, } \\
\text { шт }\end{array}$ & 14,60 & 1,27 & 7,73 & 0,12 & 0,82 \\
\hline $\begin{array}{l}\text { Вологість зерна при } \\
\text { збиранні, \% }\end{array}$ & 24,53 & 8,76 & 12,06 & 0,14 & 0,57 \\
\hline $\begin{array}{l}\text { Пошкодження } \\
\text { кукурудзяним } \\
\text { метеликом, \% }\end{array}$ & 3,10 & 8,83 & 95,70 & 0,36 & 11,59 \\
\hline Ламкість стебла, \% & 1,72 & 8,59 & 169,75 & 0,36 & 20,84 \\
\hline Вилягання стебла, \% & 2,64 & 17,85 & 160,01 & 0,52 & 19,68 \\
\hline
\end{tabular}

Залежно від генотипу і погодних умов року спостерігали значну варіацію за ознаками „пошкодження кукурудзяним метеликом”, „вилягання стебла” та „ламкість стебла”. 
Характеризуючи інбредні лінії індивідуально зафіксовано, що стабільність прояву ознаки урожайність зерна $є$ найменш мінливою $(\mathrm{V}=$ 7,90 \%) у інбредної лінії 115 (табл. 2).

Табл. 2. Варіабельність ознак проаналізованих інбредних ліній кукурудзи, 2016-2019 pp.

\begin{tabular}{|c|c|c|c|c|c|c|}
\hline \multirow{2}{*}{$\begin{array}{c}\text { Iнбредна } \\
\text { лінія }\end{array}$} & $\begin{array}{c}\text { урожайні } \\
\text { сть }\end{array}$ & $\begin{array}{c}\text { період } \\
\text { вегетації } \\
\text { „сходи-повна } \\
\text { стиглість” }\end{array}$ & $\begin{array}{c}\text { кількість } \\
\text { листків на } \\
\text { основном } \\
\text { у стеблі }\end{array}$ & $\begin{array}{c}\text { вологість } \\
\text { зерна при } \\
\text { збиранні }\end{array}$ & $\begin{array}{c}\text { висота } \\
\text { рослин }\end{array}$ & $\begin{array}{c}\text { висота } \\
\text { заклада } \\
\text { ння } \\
\text { качана }\end{array}$ \\
\hline $7 / 7$ & 30,47 & 3,65 & 4,01 & 15,26 & 16,45 & 28,76 \\
\hline 125 & 10,18 & 1,49 & 3,78 & 7,11 & 9,43 & 10,03 \\
\hline 44 & 23,07 & 2,09 & 2,64 & 7,38 & 15,10 & 28,94 \\
\hline 273 & 20,18 & 2,56 & 0,78 & 2,51 & 19,36 & 28,20 \\
\hline 73 & 15,66 & 1,88 & 1,84 & 7,00 & 21,26 & 28,16 \\
\hline 115 & 7,90 & 3,71 & 2,38 & 4,28 & 15,56 & 23,11 \\
\hline 337 & 11,99 & 2,00 & 1,44 & 6,79 & 14,55 & 22,14 \\
\hline 331 & 23,33 & 2,09 & 0,93 & 6,54 & 6,27 & 5,74 \\
\hline 053 & 16,04 & 2,23 & 2,77 & 3,60 & 10,22 & 26,44 \\
\hline 489 & 29,62 & 3,04 & 3,62 & 8,63 & 13,78 & 25,82 \\
\hline 260 & 15,48 & 1,99 & 1,88 & 10,19 & 11,46 & 22,03 \\
\hline 346 & 19,78 & 1,61 & 3,20 & 7,23 & 12,01 & 27,18 \\
\hline 333 & 12,72 & 1,60 & 2,13 & 5,46 & 9,30 & 16,13 \\
\hline 324 & 13,28 & 4,86 & 2,70 & 6,90 & 7,88 & 12,89 \\
\hline 32 & 16,92 & 1,54 & 0,97 & 4,74 & 3,96 & 11,10 \\
\hline
\end{tabular}


Близький до межі незначного варіювання був показник у інбредної лінії 125 - (V = 10,18 \%). За В. О. Сщенком [12] варіювання умовно вважають незначним, якщо коефіцієнт варіювання становить до $10 \%$, середнім - 10-20, значним - понад 20 \%. Зважаючи на зазначені критерії цей показник інбредної лінії 125 можна вважати незначним. Решта ліній під впливом умов навколишнього середовища мали мінливий показник варіювання.

Найбільші коефіцієнти варіації за врожайністю спостерігали у інбредних ліній 273, 331, 489 і 7/7. Значні показники варіабельності свідчать про недостатню стабільність зазначених інбредних ліній, а отже недостатній гомеостаз. Це лінії можуть використовуватись за створення гетерозисних гібридів інтенсивного типу для вирощування в умовах близьких до оптимальних.

Всі інбредні лінії за показниками „період вегетаціі”, та „кількість листків" на основному стеблі мали незначну мінливість, до п’яти відсотків. Найменше значення за ознакою „тривалість вегетаційного періоду” мали інбредні лінії 125, 32, 333, 346, 73 і 260, а для ознаки „кількості листків на основному стебл" - лінії 273, 331, 32, 337, 73 та 260 підтверджуючи те, що ознаки досить стійкі та не істотно залежать від умов середовища.

Більшість інбредних ліній характеризуються стабільністю за ознакою „вологість зерна'. Використання таких інбредних ліній дає можливість успішно проводити насінництво ліній, зерно яких здатне швидко втрачати вологу при дозрівання за різних погодних умов року. Інбредні лінії 7/7 і 260, що, відповідно, мали коефіцієнти варіації $\mathrm{V}=15,26$ та $\mathrm{V}=10,19$ \% належать до групи 3 середнім варіюванням адже коефіцієнт варіювання цієї ознаки перевищував десятивідсотковий рубіж.

За висотою рослин та висотою прикріплення нижнього господарсько придатного качана можна оцінювати придатність кукурудзи до механізованого вирощування і збирання врожаю. Тому важливо знати реакцію досліджуваного генотипу на умови змінних метеорологічних чинників зокрема на нестачу грунтової та повітряної вологи. 
3 колекції інбредних ліній кафедри генетики, селекції рослин та біотехнології лише одна лінія (73), за висотою рослини характеризувалася значним варіюванням. Більшість проаналізованих матеріалів було віднесено до групи з середнім варіюванням 3 коефіцієнтами 10,22-19,36 \%. Інбредні лінії 32, 331, 324, 333 і 125 складають групу 3 незначним варіюванням за висотою. Істотне коливання за ознакою „висота рослин” було виявлено у інбредної лінії 73 (V = 21,26 \%), що можна пояснити залежністю від умов навколишнього середовища.

Отримані дані вказують і на те, що висота прикріплення качана у інбредних ліній колекції $є$ мінливішим показником аніж висота рослини. Коефіцієнта варіації висоти прикріплення нижнього господарсько-придатного качана перевищував $20 \%$, у 66,7 \% інбредних ліній $(7 / 7,44,273,73$, $115,337,053,489,260,346)$ від загальної кількості що $є$ досить значним варіюванням ознаки. Незначне варіювання за ознакою висота закладання качана встановлено у інбредної лінії 331 ( $\mathrm{V}=5,74$ \%). Це свідчить про істотну стабільність лінії за цим показником. Середнім варіюванням характеризувались лінії 125, 32, 324 і 333 (V=10,03-16,13\%).

Отже, висота прикріплення нижнього господарсько-придатного качана істотно залежить від біологічних особливостей генотипу, та умов вирощування культури.

Висновки. У процесі досліджень встановлено, що інбредна лінія 331, є найстабільнішою за всіма ознаками, окрім врожайності, 3 коефіцієнтом варіювання менше $10 \%$. Вона може використовуватись за створення гетерозисних гібридів інтенсивного типу незважаючи на варіювання за врожайністю $\mathrm{V}=23,33$ \%, що пояснюється надзвичайними погодніми умовами вирощування. Доцільно використовувати інбредні лінії 125, 115, 337, 333 та 324, що поєднують високу і середню стабільність за комплексом основних господарсько-цінних ознаками. 


\section{Література}

1. Опалко А. І., Заплічко Ф. О. Селекція плодових і овочевих культур: Підручник. К.: Вища школа., 2000. 440 с.

2. Стрельчук С. І., Демідов С. В., Бердишев Г. Д., Голда Д. М. Генетика з основами селекції: підручник. К.: Фітоцентр, 2000. 292 с.

3. Тоцький В. М. Генетика: 2-е вид. Одеса: Астропринт, 2002. 712 с.

4. Eberhart S. A., Russell W. A. Yield and stability for a 10-line diallel of single crosses and double cross maize hybrids. Crop. Sci. 1969. Vol. 9. P. 47-48.

5. Овсяннікова Н. С. Взаємозв'язки між продуктивністю і елементами iï структури у ліній кукурудзи 3 різною генетичною основою. Селекиія $i$ насінництво. Харків: IP ім. Юр'єва. 2000. Вип. 84. С.72-76.

6. Алексеева Е. С., Малина М. М., Вильчинская Л. А. Изучение наследуемости некоторых признаков $\mathrm{F}_{1}$ для использования метода гибридизации в селекции гречихи. Зб. науч. тр. Междунар. конф. КаменецПодольский: Абетка, 2002. С. 81-94..

7. Бек В. Л. Теорія статистики. К., 2002.

8. Гончарук А. Г. Основи статистики: Навч. посібник. К.: Центр навчальної літератури, 2004. 125c.

9. Методика Державного сортовипробування сільськогосподарських культур. Випуск 1. К. Алефа, 2000. 100 с.

10. Методика Державного сортовипробування сільськогосподарських культур. Випуск 2. (зернові, круп'яні та зернобобові культури). Київ.: Алефа, $2001.65 \mathrm{c}$.

11. Гур'єва І.А., Рябчун В. К., Літун П. П. Методичні рекомендації польового та лабораторного вивчення генетичних ресурсів кукурудзи. Харків: Магда, 2003. 44 с.

12. Єщенко В.О., Копитко П.Г., Опришко В.П., Костогриз П. В. Основи наукових досліджень: підручник. Київ.: Дія, 2005. 288 с.

13. Гурьев Б. П., Гурьева И. А. Селекция кукурузы на раннеспелость. М.: ВО Агропромиздат, 1990. 100 с. 


\section{References}

1. Opalko, A. I., Zaplichko, F. O. (2000). Selection of fruit and vegetable crops: Textbook. K.: Higher school., 440 p.

2. Strelchuk, S. I., Demidov, S. V., Berdyshev, G. D., Golda, D. M. (2000). Genetics with the basics of selection. K.: Phytocenter, 292 p.

3. Totsky, V. M. Genetics: 2nd type. Odessa: Astroprint, 2002. 712 p.

4. Eberhart, S. A., Russell, W. A. (2000). Yield and stability for a 10-line diallel of single crosses and double cross maize hybrids. Crop. Sci. Vol. 9. Pp. 47-48.

5. Ovsyannikova, N. S. (2000). Relationships between productivity and its structure elements in maize lines with different genetic basis: Breeding and seed production. Kharkiv: IR them. Yurieva. Issue. 84. Pp.72-76.

6. Alekseeva, E. S., Malina, M. M., Vilchinskaya, L. A. (2002). Study of the inheritability of some $F_{1}$ traits for the use of the hybridization method in buckwheat breeding. Coll. scientific tr. International. conf. Kamenets-Podolsky: Abetka. Pp. 8194.

7. Beck, W. L. Theory of statistics. K., 2002.

8. Goncharuk, A. G. (2004). Fundamentals of statistics: Textbook. manual. K .: Center for Educational Literature, 125p.

9. Methods of state variety testing of crops. Issue 1. K. Alefa, 2000. 100 p.

10. Methods of state variety testing of crops. Issue 2. (cereals, cereals and legumes). K .: Alefa, 2001. $65 \mathrm{~s}$.

11. Gurieva, I. A., Ryabchun, V. K., Litun, P. P. (2003). Methodical recommendations of field and laboratory study of genetic resources of corn. Kharkiv: Magda, 44 p.

12. Yeshchenko, V. O., Kopytko, P. G., Opryshko, V. P., Kostogryz, P. V. (2005). Fundamentals of scientific research: Textbook. K.: Action. 288 p.

13. Guryev, B. P., Guryeva, I. A. (1990). Selection of corn for early ripening. M.: VO Agropromizdat, 100 p. 


\section{Аннотация}

Коциоба С. П.

\section{Характер изменчивости инбредных линий кукурузы в условиях Правобережннй Лесостепи Украины}

На современном этапе развития селекционной науки инбредные линии являются основнылм источником для создания новых генотипических комбинацчий для различных селекционных программ. В наших исследованиях решение о включении исходного материала в программы создания гибридов принимали с учетом вариабельности инбредных линий по отдельным признакам и проявления их производительного потенц̧иала.

Относительно урожайности, статистические характеристики указывают на то, что дисперсия $\left(S^{2}=0,68\right)$ низкая, а значит инбредные линии, входящчие в коллекциюю незначительно реагируют на колебания условий вырашивания изменением урожайности. B то же время небольшое (V= 4,96\%) варьирование продолжительности периода от всходов до полной спелости и количества листьев на основном стебле ( $V=7,73 \%)$, указывает на выравненность коллекциии по этим показателям. Небольшая вариабельность показателей влажности зерна при уборке $\left(S^{2}=8,76 ; V=12,6 \%\right)$ свидетельствует о перспективах данного критерия, как дополнительного, в оценке уровня скороспелости исследуемого селекционного материала.

В зависимости от генотипа и погодных условий года наблюдалась значительная вариация признаков "повреждения кукурузным мотыльком", "полеганию стебля" и "ломкость стебля". Наибольшие коэфффициентьл вариацуии по урожайности наблюдали в инбредных линий 273, 331, 489 и 7/7. Высокие показатели вариабельности свидетельствуют о недостаточной стабильности указанных линий, а значит недостаточный гомеостаз. Такие линии могут использоваться при создании гетерозисньх гибридов интенсивного типа для выращивания в условиях близких к оптимальным. 
Установлено, что инбредная линия 331, наиболее стабильная по всем признакам, кроме урожайности, с коэффициентом варьирования не более $10 \%$ Она может быть использована при создании гетерозисных гибридов интенсивного типа несмотря варьирование по урожайности, что $V=23,33 \%$. можно объяснить чрезвычайными условиями выращивания.

Ключевые слова: кукуруза, инбредная линия, изменчивость, вариабельность, дисперсия, коэфициент вариации

\section{Annotation}

Kotsiuba S.P.

Character of variability of inbred lines of corn in condition of Right-bank Forreststeppe of Ukraine

At the present stage of the development of breeding science, inbred lines are the main source for creating new genotypic combinations for various breeding programs. In our studies, the decision to include the source material in the programs for creating hybrids was made taking into account the variability of inbred lines for individual characters and the manifestation of their productive potential.

Regarding crop yields, statistical characteristics indicate that the variance $\left(S^{2}\right.$ $=0,68)$ is low, which means that the inbred lines included in the collection do not respond significantly to fluctuations in growing conditions by changing yields. At the same time, a small ( $V=4,96 \%)$ variation in the length of the period from seedlings to full ripeness and the number of leaves on the main stem $(V=7,73 \%)$ indicates that the collection is even in these indicators. The small variability of grain moisture indicators during harvesting ( $S 2=8,76 ; \mathrm{V}=12,6 \%$ ) indicates the prospects of this criterion, as additional, in assessing the early maturity level of the studied material.

Depending on the genotype and weather conditions of the year, there was a significant variation in the signs of "damage by the corn moth", "lodging of the stem" and "fragility of the stem". The highest variation coefficients in yield were observed in inbred lines 273, 331, 489, and 7/7. High rates of variability indicate 
insufficient stability of these inbred lines, which means insufficient homeostasis. Such lines can be used to create intense heterotic hybrids for growing under conditions close to optimal.

It was established that the inbred line 331, the most stable in all respects except yield, with a coefficient of variation of not more than $10 \%$. It can be used to create intensive heterosexual hybrids despite varying yields, which is $V=23,33 \%$. can be explained by extreme growing conditions.

Keywords: corn, inbred line, variability, variability, variance, coefficient of variation

УДК: 633.26:631.67:631.71

DOI 10.31395/2415-8240-2020-96-1-405-416

\title{
УРОЖАЙНІСТЬ І ТЕХНОЛОГІЧНА ЯКІСТЬ НАСІННЯ СОЇ ЗАЛЕЖНО ВІД ОСНОВНОГО ОБРОБІТКУ ГРУНТУ І ПОПЕРЕДНИКІВ У ПРАВОБЕРЕЖНОМУ ЛІСОСТЕПУ УКРАЇНИ
}

\author{
І. А. ПОКОтИЛО, кандидат сільськогосподарських наук \\ Білоцерківський національний аграрний університет \\ В. Г. КРИЖАНІВСЬКИЙ, кандидат сільськогосподарських наук \\ В. І. НЕВЛАД, кандидат сільськогосподарських наук \\ Уманський національний університет садівництва
}

В статті показано особливості формування продуктивності сої залежно від попередників $і$ обробітку трунту. Встановлено, щчо в Правобережному Лісостепу Украӥни на чорноземах типових середньосуглинкових найвищу врожайність сої на рівні 3,50-3,70 $\mathrm{m} / 2$ а забезпечило розміщення ї̈ після зернових колосових культур за безполицевого обробітку трунту на 20-22 см 